\title{
HAK ASASI MANUSIA BERAGAMA DALAM PERSPEKTIF TAFSIR IZWAJI (HUMAN RIGHTS IN THE PERSPECTIVE OF IZWAJI'S TAFSIR)
}

\author{
Musthofa \\ Sekolah Tinggi Agama Islam (STAI) Madiun \\ mustofa030858@gmail.com
}

\section{Abstract}

Religious human rights, is the right of a person to embrace a religion that is believed to be true. Basically, religious human rights are one's freedom to embrace a religion that is believed to be true. Human Rights in the Perspective of Izwaji's Tafsir includes: First, the right of faith, including pledges by word of mouth, justification with the heart and justification through the deeds of the limbs. Second, the right to practice includes the principle of compliance, the principle of fulfillment, the right of principle and justice. Third, the right to protection, including physical and legal protection, includes the expression of thought, preaching, which includes freedom, rational and universal preaching, and protection of maisyah (economic resources) among fellow believers.

Keywords: right of faith, right of practice, right of protection

\section{A. PENDAHULUAN}

Hak Asasi Manusia (HAM) beragama adalah suatu hak seseorang yang melekat pada dirinya untuk mempercayai dan memeluk suatu agama yang diyakini kebenarannya, dan mendapatkan perlindungan bagi pemeluknya.

HAM beragama bagi seseorang mempunyai tuntutan hidup yang mendasar, mengenai kebebasan hak untuk memeluk suatu agama guna memenuhi 
kebutuhan hidupnya, dalam hubungannya dengan agamanya. Tuntutan hidup ini menyangkut kepercayaan, pengalaman, dan perlindungan pada dirinya. Hal ini telah dituangkan dalam UU RI no. 29 tahun 1999 pasal 22 tentang Hak Asasi Manusia, bahwa setiap orang bebas memeluk agamanya masing-masing dan beribadah menurut agama dan kepercayaannya.

HAM beragama merupakan tuntutan hidup seseorang untuk memilih dan memeluk suatu agama yang dipercayai kebenarannya. Dalam pandangan Islam, memeluk suatu agama, merupakan hak seseorang, tidak ada unsur tekanan dan paksaan untuk memeluknya. Ini telah ditegaskan dalam Al-Quran yang artinya, "Tidak ada paksaan di dalam suatu agama."

HAM Beragama ini dilindungi oleh Undang-Undang dan ajaran agama Islam. Ini perlu dilaksanakan dengan tulus oleh para pemeluk masing-masing, agar mendapat perlindungan. Jaminan kebebasan memeluk suatu agama, sesuai dengan pemenuhan hak asasi manusia. Hal ini sesuai dengan pendapat Budiardja, bahwa hak asasi manusia adalah jaminan akan hak yang dimiliki oleh setiap individu bersama dengan keberdayaannya, dalam kehidupan masyarakat, tanpa membedakan ras, bangsa, suku, agama, kenis kelamin. ${ }^{2}$

Hafniati dalam tulisannya menyebutkan bahwa dalam konteks keindonesiaan, Hak Asasi Manusia menemukan relevansinya apabila dibangun berdasarkan orientasi maqasid as-syari'ah (tujuan-tujuan dasar syariah), yakni mewujudkan dan menjaga kebaikan serta kemakmuran masyarakat. kepentingan masyarakat, ini kemudian dikenal dengan sebutan mashlahah 'ammah. ${ }^{3}$

Aisyah dalam tulisannya bahwa sepanjang prinsip HAM dalam al-Qur'an dipahami sebagaimana pesan universalnya, maka akan tetap relevan dengan kehidupan. Lebih dari itu, prinsip tersebut dapat membentuk masyarakat yang bermartabat dan saling menghargai, tetapi jika prinsip universal al- Qur'an berusaha dijabarkan secara partikularistik, maka bisa saja mereduksi universal-

\footnotetext{
${ }^{1}$ QS. Al-Baqarah: 256.

2 J. Suyuthi Pulungan, Universalisme Islam, Jakarta: PT. Moyo Segoro Agung, 2002, hal. 157.

3 Hafniati, Hak Asasi Manusia Dalam Islam, Al-Adyan, P-ISSN: 1907-1736, E-ISSN: 2685-3574 Vol. 3, No. 2, Juli - Desember, 2018, DOI: https://doi. org/10.24042/ajsla.v13i2. http://ejournal.radenintan.ac.id/index.php/alAdyan/ article/view/3843 lihat juga Ahmad Nur Fuad, dkk. "Islam and Human Rights in Indonesia: An Account of Muslim Intellectual." Al-Jami'ah Journal Of Islamic Studies (UIN Sunan Kalijaga Yogyakarta) 45, no. 2 (2007/1428). Lihat juga Kurniawan Kunto Yuliarso, Nunung Prajarto. "Hak Asasi Manusia (HAM) Di Indonesia: Menuju Democratic Governance." JSP: Jurnal Ilmu Sosial Dan Ilmu Politik 8, no. 3 (Maret 2005).
} 
itas al-Qur'an dan itu artinya membatasi kuluesan al-Qur'an sebagai kitab yang shalih li kulli zaman wa makan wa hal. ${ }^{4}$

Beberapa konsep tersebut dapat dinarasikan bahwa, hak asasi manusia beragama, merupakan hak individu untuk memeluk suatu agama, yang mendapatkan hak perlindungan baginya.

Namun, kenyataan yang ada pada sebagian masyarakat menunjukkan, bahwa adanya pemaksaan untuk memeluk pada suatu agama tertentu, sehingga yang menjadi permasalahan adalah, "Bagaimana pandangan Islam terhadap orang yang menggunakan hak kebebasan dalam keimanan, pengamalan dan perlindungan dalam memeluk suatu agama."

Artikel ini merupakan susunan karya tulis yang bersumber dari bukubuku atau literatur yang berhubungan dengan pembahasan ini. Metode pendekatan melalui pendekatan Tafsir Izwaji, artinya penjelasan yang didasarkan atas nas Al-Quran dan al-hadits, serta pendapat para ulama dan para ahli yang berhubungan dengan pembahasan ini. Artikel ini disusun melalui sistematika: Pendahuluan, Hak Asasi Manusia Beragama, dan Kesimpulan.

\section{B. HAK ASASI BERAGAMA DALAM PERSPEKTIF TAFSIR IZWAJI}

Hak Asasi Manusia pada dasarnya menekankan pada kebebasan hidup bagi seseorang termasuk hak asasi manusia beragama. Kebebasan ini dipandang dari sudut ajaran Islam yang didasarkan atas tafsir yang didapat dari AlQuran, al-hadits, dan pendapat para ulama atau para ahli yang berhubungan dengan pembahasan ini. Dalam Konsep Universalisme didasarkan atas pendapat J. Suyuthi Pulungan, bahwa kebebasan diperlukan menurut Al-Quran adalah kebebasan beragama, kebebasan dari rasa takut, kebebasan berbicara dan menyatakan pendapat, kebebasan berpolitik, kebebasan dari penindasan dan perbudakan. ${ }^{5}$ Agar nampak keterangan lebih jelas daapt diikuti penjelasan berikut ini.

Kebebasan beragama, artinya suatu kebebasan yang dituntut oleh seseorang untuk memeluk suatu agama yang diyakini kebenarannya. Kebebasan ini tercantum dalam Al-Quran, yaitu:

\footnotetext{
4 Aisyah, Hak Asasi Manusia Dalam AL Qur'an, Tafsere Vol. 2 No. 12014 dalam http://journal.uin-alauddin.ac.id/index.php/tafsere/article/view/7457

5 J. Suyuthi Pulungan, Universalisme Islam, Jakarta: PT. Moyo Segoro Agung, 2002, hal. 162.
} 


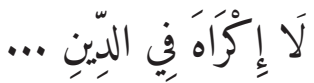

Artinya: "Tidak ada paksaan untuk (memasuki) agama"

Ayat Al-Quran ini menunjukkan bahwa tidak ada larangan paksaan pada suatu agama, berati ini membutuhkan bahwa ada perlindungan kebebasan bagi seseorang untuk memeluk pada suatu agama.

Kebebasan beragama diberikan kepada umat manusia di dalamnya ada nilai-nilai kerukunan antarumat beragama, dari berbagai agama yang ada di seluruh dunia ini.

Kerukunan antarumat, termasuk umat dalam lintas agama, ini dilakukan dengan saling mengenal antara laki-laki dan perempuan sebagai makhluk Allah, walaupun terdapat perbedaan profesi, perbedaan ras, perbedaan agama, karena Al-Quran memberikan pembelajaran kepada seluruh umat manusia. dungan.

Pada bagian ini akan disajikan tentang hak iman, hak tauhid dan perlin-

\section{Iman (Percaya)}

Menurut sabda Rasulullah saw, bahwa: "Iman adalah ikrar dengan lisan, pembenaran dengan hati, dan beramal dengan anggota." ${ }^{6}$ Yaitu:

Pertama, hak ikrar dengan lisan, artinya iman dapat diketahui dengan ikrar melalui lisan. Pernyataan diri berisi tentang pengakuan yang diucapkan dalam lisan. Ini telah dilakukan oleh Firaun ketika hampir tenggelam, bahwa, "Saya percaya bahwa tidak ada tuhan melainkan Tuhan yang dipercaya oleh orang Bani Israil." Ikrar Firaun ini menunjukkan ada kebebasan dalam mengikrarkan iman dihadapan kaum Bani Israil saat itu walaupun berbeda Tuhan yang mereka percayai.

Ikrar lisan ini merupakan bentuk komunikasi antara seorang pemeluk agama dengan Tuhan Yang Maha Gaib. Keberadaan Tuhan yang tidak dapat diketahui dengan panca indera, tapi diwujudkan dengan pernyataan, ikrar dengan lisan. Iman berupa kepercayaan dengan ikrar lisan ini menunjukkan keberadaan Tuhan yang walaupun tidak dapat dibuktikan dengan alat yang lain, kecuali dengan kepercayaan semata. Dalam Teori Aksioma diterangkan bahwa, pembenaran pada sesuatu atas dapat kepercayaan dinilai sebagai pembenaran

\footnotetext{
6 Abi Bakar Muhammad bin Ishak Al-Kalabadzi, Al-Tåarruf Limadzabibi Abli Al-Tasawwuf, Beirut: Darul Kutub Al-Ilmiyah, 1993 M, hal. 88.

QS. Yunus: 90.
} 
yang sah. Loren Bagus menerangkan bahwa, aksioma adalah pernyataan dalam ilmu pengetahuan yang dibangun sedemikian, sehingga pernyataan ini diambil sebagai titik mula dan tidak usah dibuktikan dalam teori yang bersangkutan. ${ }^{8}$

Ikrar tentang bukti iman kepada Tuhan yang telah dipercaya dapat berguna bagi dirinya, bahwa dirinya telah mengikrarkan imannya kepada Tuhan yang dipercayainya supaya orang lain mengetahui dan menghargai terhadap kepercayaan kepada Tuhan selain Tuhan yang ia percayainya.

Ikrar bukti iman dapat menjadikan dirinya tidak mengganggu terhadap agama yang telah dipercayai orang lain. Karena ikrar ini dapat membatasi dirinya tidak mengikrarkan kepercayaan agama orang lain, ini dinilai sebagai orang munafik. Munafik itu akan terjun ke jalan yang sesat. Hal ini telah dijelaskan dalam Tafsir Ibnu Katsir yang artinya: Mereka (orang munafik) telah keluar dari jalan Al-Haq (benar), masuk ke dalam jalan yang sesat.' Bentuk ancaman berupa sebutan seorang munafiq menunjukkan ketidakpatuhan terhadap agamanya sendiri. Dalam Teori Kepatuhan bahwa ancaman menunjukkan hukuman akan dikenakan bagi yang tidak patuh. ${ }^{10}$ Orang yang tidak patuh beragama, menunjukkan perlawanan terhadap ikrar yang telah disampaikannya dinilai sebagai munafiq. Dapat dikatakan bahwa ketidakpastian dalam ikrar - iman menunjukan sikap munafiq dalam norma agama. Sikap munafiq ini dapat mengganggu kebebasan beragama bagi orang lain.

Kedua, hak pembenaran dengan hati. Iman merupakan pembenaran yang terletak dalam hati seseorang. Ini dapat diketahui oleh dirinya sendiri, orang lain tidak dapat mengetahui iman dalam kalbu ini. Seseorang yang telah beriman yang melekat pada hati dapat menjadikan diri tidak akan mengganggu kepercayaan agama orang lain. Karena kepercayaan yang melekat pada kalbu tidak bisa dipengaruhi orang lain, sehingga iman yang sudah melekat pada kalbu seseorang tidak akan mengganggu dan tidak mudah diganggu oleh kepercayaan agama lain. Ini menunjukkan adanya toleransi terhadap sesama kepercayaan beragama. Iman dalam kalbu nanti akan diminta pertanggungjawabannya oleh Allah. Karena ditegaskan dalam Al-Quran, "Sesungguhnya pendengaran, penglihatan, dan hati nurani semua akan diminta pertanggungjawabannya."11

Iman dalam kalbu adanya kecenderungan mencari ketenangan yang mantap. Firman Allah, artinya: "Belumkah kami beriman? Ibrahim menjawab, aku

\footnotetext{
8 Marisson, Op.Cit, hal. 162.

9 Ibnu Katsir, Tafsir Al-Quranul Adzim, Cet. II Jilid 4, tt, hal. 172.

${ }^{10}$ Marisson, Op.Cit, hal. 162.

${ }^{11}$ QS. Al-Isra': 176.
} 
telah beriman (meyakininya) hatiku tetap mantap (tenang),"12 sehingga tidak akan mengusik ketenangan orang lain, termasuk kepercayaan agama orang lain. Iman dalam kalbu dapat mengakibatkan terbentuknya semua kebaikan, sehingga tidak akan mengganggu ketenangan orang lain, termasuk mengganggu ketenangan kepercayaan agama orang lain. Rasul bersabda, artinya: "Ingatlah, sesungguhnya pada jasad terdapat gumpalan daging, apabila ia akan baik maka keseluruhannya akan baik, apabila ia rusak maka keseluruhannya akan menjadi rusak. Ingatlah bahwa dia adalah hati (kalbu)." ${ }^{13}$ Hadits ini menunjukkan bahwa iman dalam kalbu dapat membentuk kebaikan kalbu, apabila kalbu itu baik akan mempengaruhi kebaikan terhadap semuanya termasuk tidak mau mengganggu kepercayaan agama lain. Ini menunjukkan bahwa jika iman dalam hati (kalbu) dapat menjaga toleransi umat beragama.

Ketiga, hak iman, pembenaran melalui beramal dengan perbuatan anggota badan. Iman dapat diketahui melalui perbuatan dan amal seseorang. Semakin kuat iman seseorang ada kecenderungan semakin baik amal seseorang. Semakin baik amal seseorang semakin menciptakan kedamaian di antara orang lain dan termasuk dirinya sendiri. Iman dan amal salih merupakan hubungan yang tidak dapat dipisahkan. Al-Quran menyebutkan, artinya: "Orang yang beriman serta beramal salih, mereka itu penghuni surga." ${ }^{14}$

Surga yang diterangkan dalam Al-Quran merupakan simbol kebahagiaan dan perdamaian. Ini akan mempengaruhi amal seseorang, apabila iman seseorang semakin kuat, akan mempengaruhi amal mereka pada amal yang salih. Amal salih terhadap orang lain merupakan bukti kebaikan dirinya kepada orang lain merupakan bukti kebaikan dirinya kepada orang lain termasuk orang yang berbeda iman pada suatu agama yang berbeda. Iman dan amal salihapabila terjadi interaksi dengan orang lain. Interaksi didasari amal salih akan mendapatkan amal salih dari orang lain atas dasar interaksi tersebut. Menurut psikologi sosial dalam Teori Pertukaran bahwa, pertukaran sosial bertujuan untuk mendapatkan ganjaran, ganjaran intrinsik, kasih sayang, kehormatan atau kecantikan. ${ }^{15}$

Iman dalam bentuk amal salih dapat mengakibatkan perilaku sosial yang baik. Ini dapat menjadikan interaksi yang baik terhadap orang lain termasuk

\footnotetext{
${ }^{12}$ QS. Al-Baqarah: 260.

${ }^{13}$ Abu Abd. Allah bin Muhammad bin Ismail Al-Bukhari, Shahih Bukhari, Juz III Cet. 3, Beirut: Dar Ibnu Katsir, 1981, No. 52.

${ }^{14}$ QS. Al-Baqarah: 82.

${ }^{15}$ Margaret M. Polma, Sosiologi Kontemporer, Jakarta: PT. Raja Grafindo Persada, 2000, hal. 82.
} 
orang yang mempunyai kepercayaan pada suatu ajaran yang berbeda, sehingga iman dalam bentuk amal salih dapat melindungi hak seseorang untuk beragama walaupun pada agama lain kepercayaan yang berbeda.

\section{Hak Pengamalan}

Hak pengamalan artinya pembuktian kepercayaan pada ajaran-ajaran suatu agama yang dianutnya dalam bentuk gerakan fisik atau mental, didasarkan atas prinsip kepatuhan, prinsip pemenuhan hak, dan prinsip keadilan.

Pertama, Prinsip Kepatuhan. Pengamalan-pengamalan suatu agama terdapat perbedaan dengan agama lain. Perbedaan ini terjadi atas dasar pada kepatuhan tentang tatacaranya beribadah, tempat dan gerakan-gerakannya. Hal ini didasari firman Allah:

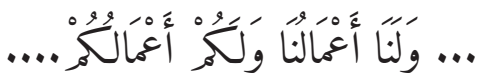

Artinya: "bagi kami amalan kami, dan bagi kamu amalan kamu"16

Bentuk pengamalan ini didasarkan atas kepercayaan masing-masing pada ajaran suatu agama. Ini memberikan pengertian bahwa adanya kebebasan bagi seseorang untuk mengamalkan ajaran-ajarannya masing-masing. Pengamalan ajaran suatu agama didasari atas kepatuhan pada Tuhan yang menciptakan ajaran agama itu. Ini didasari adanya janji berupa pahala dari pengamalan itu. Menurut Teori Kepatuhan yang digagas oleh Maxwel dan Schmitt, bahwa strategi mendapatkan kepatuhan adanya janji, yaitu menjanjikan hadiah bagi kepatuhan. ${ }^{17}$ Kepatuhan merupakan kelanjutan dari ketaatan mengamalkan suatu ajaran suatu agama, sebab ketaatan beramal suatu ajaran agama bukan karena adanya paksaan dari orang lain, akan tetapi atas dasar hidayah (petunjuk) yang datang dari Tuhan. Firman Allah yang

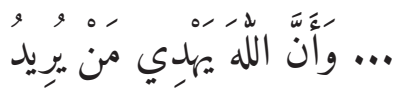

Artinya: "dan bahwasanya Allah memberikan petunjuk kepada siapa yang Diakehendaki."

Pengamalan suatu ajaran atas dasar petunjuk Allah, bukan karena tekan-

\footnotetext{
${ }^{16}$ QS. Al-Baqarah: 139.

${ }^{17}$ Marisson, Teori Komunikasi Individu hingga Massa, Jakarta: Kencana Prenada Media Grup, 2013, hal. 162.

${ }^{18}$ QS. Al-Hajj: 16.
} 
an atau paksaan dari orang lain. Ini menunjukkan bahwa hak seseorang untuk mengamalkan suatu ajaran agama perlu dihormati.

Kedua, Prinsip Penenuhan Hak. Pengamalan suatu agama atas dasar pemenuhan hak asasi manusia, artinya semua pemeluk suatu agama diberi hak untuk mengamalkan ajaran agama masing-masing. Hal ini dikemukakan oleh J. Suyuthi Pulungan, bahwa esensi hak asasi manusia terletak pada azas persamaan manusia. Setiap individu terlahir sama dan harus memperoleh kesempatan yang sama untuk berkembang, beramal dan berkarya. ${ }^{19}$

Pengamalan agama merupakan hak seseorang yang perlu diberi kebebasan, tiada paksaan untuk mengamalkan ajaran suatu agama tertentu, sehingga para pemeluk agama yang terdiri dari berbagai suku, ras, jenis kelamin diberi hak yang sama. Ini dilakukan bertujuan agar setiap individu dihargai sebagai perannya dan penghargaan hak sesama manusia yang dinamakan hak egalitarianisme.

Menurut Budiardjo yang dikutip oleh salah seorang ahli yaitu J. Suyuthi Pulungan, bahwa semangat egaliterian, hak asasi manusia adalah jaminan akan hak yang dimiliki oleh setiap individu bersamaan dengan keberadaannya dalam kehidupan masyarakat tanpa membedakan ras, bangsa, suku, agama, jenis kelamin, dan seterusnya. ${ }^{20}$

Ketiga, Prinsip Keadilan. Pengamalan ajaran suatu agama perlu ditegakkan mengenai keadilan, tanpa memandang status sosial masing-masing individu antara yang miskin dan yang kaya, antara pejabat dan rakyat, antara laki-laki dan perempuan diberi hak yang sama untuk mengamalkannya, termasuk ganjaran bagi tiap-tiap pemeluk suatu agama.

Prinsip pengamalan suatu agama mengenai perintah pada ajaran suatu agama dibebankan kepada pemeluk agama masing-masing, tanpa pandang bulu. Hal ini ditegaskan dalam Al-Quran,

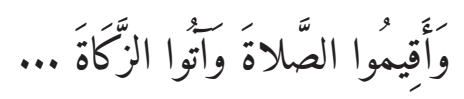

Artinya: "Dirikanlah salat dan berikan zakat."

Ini menunjukkan adanya perintah mengamalkan suatu ajaran agama tanpa memandang jenis kelamin maupun status sosial.

Prinsip pengamalan suatu agama mengenai larangan untuk mengamalkan

\footnotetext{
19 J. Suyuthi Pulungan, Op.Cit, hal. 157.

${ }^{20} \mathrm{~J}$. Suyuthi Pulungan, Op.Cit, hal. 157.

${ }^{21}$ QS. Al-Baqarah: 110.
} 
suatu ajaran agamanya. Ini dilakukan karena adanya unsur ketaatan pada larangan untuk ditinggalkannya, dalam Al-Quran dijelaskan,

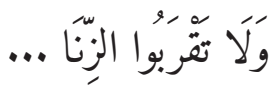

Artinya: "Janganlah engkau mendekati perbuatan zina."22

Ini menunjukkan adanya pengamalan untuk ditinggalkan, karena kalau ini dilakukan akan merubah tatanan sosial.

Prinsip keadilan ini telah dilakukan oleh Rasul ketika berhadapan dengan kaum Qurais yang hidup berkasta-kasta, dan agama beragam, dan orang telah dibencinya. Hal ini dijelaskan dalam Al-Quran,

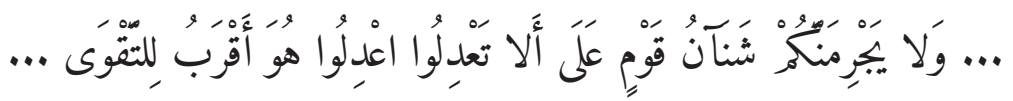

Artinya: "Dan janganlah sekali-kali kebencianmu terhadap suatu kaum, mendorong kamu untuk berlaku tidak adil. Berlaku adillah, karena adil itu lebih dekat kepada takwa." ${ }^{\text {23 }}$

Perintah adil terhadap semua kaum yang bersifat umum tidak melindungi perbedaan klaster sosial maupun perbedaan agama. Ini memberi pembelajaran lewat keadilan supaya tetap terjada agar kerukunan umat, termasuk umat beragama.

Prinsip pengamalan berupa perintah untuk menunaikan dan larangan untuk menjauhi, ini berlaku untuk semua oemeluk masing-masing agama agar terwujud keadilan. Ini bertujuan agar kerukunan umat beragama terjada.

\section{Hak Perlindungan}

Hak perlindungan artinya memberi pengamanan kepada orang yang memeluk suatu agama. Perlindungan ini dilakukan dengan cara memberi pengamanan fisik, hukum (pemikiran dakwah dan maisyah).

Pertama, perlindungan fisik, artinya para pemeluk suatu agama yang dianutnya wajib dilindungi haknya dari ancaman yang mengganggu keselamatan fisik mereka dalam beragama. Perlindungan fisik dilakukan dengan cara memberikan kebebasan dan menjamin keselamatan bagi pemeluk suatu agama untuk melakukan ibadah maupun bergaul dengan

\footnotetext{
${ }^{22}$ QS. Al-Isra': 32.

${ }^{23}$ QS. Al-Maidah: 8.
} 
sesama manusia daru ancaman dan gangguan.

Perlindungan ini diberikan agar pemeluk suatu agama dapat hidup nyaman tidak terusik kebebasannya dalam menajalankan peribadatan agama masing-masing. Dalam Al-Quran disebutkan,

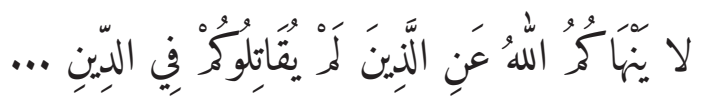

Artinya: "Allah tidak melarang kamu berbuat baik dan berlaku adil terhadap orang dengan tidak memerangimu karena agama."24

Ayat ini menunjukkan bahwa tidak dibenarkan memerangi kepada orang lain karena agama (pemeluk agama yang berbeda). Dapat dikatakan bahwa kandungan ayat $\mathrm{Al}$-Quran ini, menunjukkan adanya toleransi terhadap agama yang berbeda, dengan cara memberi ruang kepada orang lain memeluk agama sesuai dengan kepercayaannya. Perlindungan keamanan ini telah dicontohkan oleh Rasul saw ketika beliau merintis pembangunan kota Madinah, bahwa, di kala Madinah terdiri dari kaum muslimin, bangsa Yahudi (Bani Nadir dan Bani Quraizhah) dan bangsa Arab yang belum menganut agama Islam, menghukum orang yang berbuat kerusakan, memberi keamanan kepada orang yang patuh, kebebasan agama terjamin buat semua. ${ }^{25}$

Perlindungan ini juga telah disabdakan oleh Rasul, artinya: "Ya Allah, sesungguhnya aku mohon perlindungan-Mu hari yang buruk, malam yang buruk, waktu yang buruk, teman yang buruk, tetangga yang buruk pada tumah tempat tinggal." 26

Ringkasan keterangan bahwa perlindungan umat beragama perlu diwujudkan, berupa perlindungan fisik dari serangan lawan dan memberi pengamanan bagi pemeluknya.

Kedua, Perlindungan Hukum. Pemeluk suatu agama diberi hak sepenuhnya perlindungan hukum, agar dijamin keselamatan dalam memeluk suatu agama.

Perlindungan hukum ini berlaku untuk semua pemeluk suatu agama, terutama para pemeluk agama minoritas pada suatu wilayah atau suatu negara tertentu. Ini pernah dilakukan oleh Rasul saw ketika membangun kota Madinah, beliau memulai pembangunan kota ini dengan cara membangun kerukunan

\footnotetext{
${ }^{24}$ QS. Al-Mumtahanah: 8.

${ }^{25}$ A. Sya'labi, Sejarah dan Kebudayaan Islam, Jakarta: Percetakan Mutiara Sumber Wijaya, 2000, hal. 118-119.

${ }^{26}$ Abu Bakar As-Suyuthi, Op.Cit, hal. 60.
} 
antar umat beragama di kota Yatsrib yang sekarang dinamakan kota Madinah, yaitu hubungan persahabatan dengan pihak-pihak lain yang tidak beragama Islam. Di Madinah, di samping orang-orang Arab Islam, juga terdapat golongan masyarakat Yahudi dan orang-orang Arab yang masih menganut agama nenek moyang mereka, diadakan perjanjian di antara mereka yang dinamakan Konstitusi Madinah. ${ }^{27}$

Perlindungan hukum umat beragama merupakan hak setiap insan, ini juga disebutkan dalam Al-Quran, artinya: “Tidak ada paksaan untuk (masuk) agama Islam." 28

Perlindungan umat beragama juga dijelaskan dalam hadits Nabi, artinya: "Siapapun yang memerangi kafir mu'ahad, dia tidak akan mendapatkan wanginya surga." 29

\section{a. Perlindungan hukum mencakup, dalam ekspresi pemikiran, dakwah, dan maisyah (sumber kehidupan).}

Pertama, Perlindungan dalam ekspresi pemikiran, yaitu payung hukum yang memberikan kesempatan, keselamatan dalam mengamalkan pemikiran di masyarakat. Perlindungan ini dilakukan dengan cara mengemukakan pendapat hasil pemikiran yang bernilai kebaikan dan membaur kemaslahatan di masyarakat, misalnya pemikiran yang mengandung nilai akblakul karimah. Ini dilakukan agar masyarakat memiliki pengetahuan dan pemahaman tentang akblakul karimah. Perlindungan hukum tentang ekspresi pemikiran mengenai akblakul karimah ini ditegaskan dalam Al-Quran,

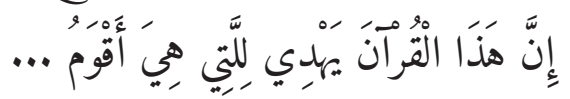

Artinya: "Sesungguhnya Al-Quran ini memberi petunjuk ke (jalan) yang paling lurus." 30

Jalan yang lurus yang dimaksud dalam ayat ini adalah petunjuk yang mengarah kepada nilai akblakul karimah. Rasul juga memperkuat tentang ekspresi pemikiran akblakul karimah dalam sabdanya, artinya: "Sungguh aku diutus

\footnotetext{
${ }^{27}$ Badrul Yatim, Sejarah Peradaban Islam, Dirasah Islamiyah, Jakarta: Raya Grafindo Persada, 2000, hal. 26.

${ }_{28}$ QS. Al-Baqarah: 256.

${ }^{29}$ Abu Abd. Allah Muhammad bin Ismail al-Bukhari al-Ja’afi, Shabih Bukhari, Juz III Cet. Ke-3, Bairut: Dar Ibnu Katsir, 1987, hal. 1155.

${ }^{30}$ QS. Al-Isra': 9.
} 
untuk menyempurnakan akhlak yang salih." ${ }^{31}$

Ekspresi pemikiran tentang akblakul karimah ini merupakan bentuk nilai kesopanan yang menjadi nilai universal dalam budaya masyarakat. Ini telah dikemukakan oleh Brown dan Levinson, bahwa kesopanan seringkali merupakan tujuan, karena kesopanan merupakan nilai universal secara kultural. ${ }^{32}$

Ekspresi pemikiran tentang akhlakul karimah dapat berguna bagi kehidupan, yaitu untuk memberi petunjuk kepada seseorang agar berperilaku yang mengandung nilai-nilai yang mulia, sehingga diperlukan perlindungan dalam pemenuhan asasi bagi orang yang mengamalkan suatu ajaran agama.

Kedua, Perlindungan hukum dalam dakwah. Perlindungan dakwah yaitu pengayoman terhadap dakwah dalam pengembangan wilayah, memperoleh dukungan dan pengikut yang diinginkan, sesuai dengan agamanya. Ini dapat dilakukan dengan cara amar makruf dan nabi munkar. Amar makruf artinya, mengajak kepada masyarakat untuk beramal yang baik sesuai dengan ajaran agamanya.Nahi munkar artinya, melarang para pengikut atau orang lain untuk berbuat buruk. Hal ini telah mendapatkan perlindungan hukum dalam Al-Quran,

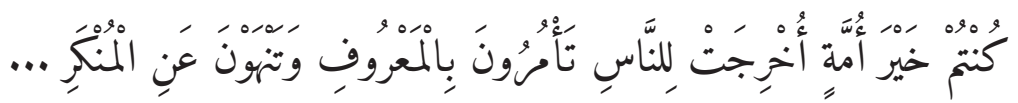

Artinya: "Kamu adalah umat yang baik yang dilabirkan untuk manusia menyurub kepada yang makruf (baik) dan mencegah dari yang munkar (buruk)."33

Perlindungan dakwah suatu agama ini juga ditegaskan dalam hadits Nabi, artinya: "Perkataan anak Adam semuanya, tidaklah baginya kecuali perintah yang makruf atau mencegah yang munkar atau ingat kepada Allah." ${ }^{34}$

Perlindungan hukum tentang dakwah ini juga dilaksanakan Nabi ketika beliau berada di kota Thaif, bahwa Nabi menyeru orang-orang terkemuka di kota itu agar bertaubat kepada Tuhan. ${ }^{35}$

Perlindungan hukum tentang dakwah ini merupakan bentuk komunikasi yang menghasilkan kepercayaan. Semakin banyak berkomunikasi yang posi-

\footnotetext{
${ }^{31}$ Al-Iman Jalaluddin Abdu Al-Rahman bin Abi Bakar Al-Suyuthi, Al-Jamiul Al-Shaghir, Bandung-Indonesia: Syirkah Al-Maarif, tt, hal. 103.

${ }^{32}$ Marisson, Op.Cit, hal. 171.

${ }^{33}$ QS. Ali Imron: 110.

${ }^{34}$ Abu Bakar Al-Suyuthi, Op.Cit, hal. 98.

${ }^{35}$ A. Sya'labi, Op.Cit, hal. 99.
} 
tif akan mendapatkan kepercayaan yang positif pula. Kepercayaan masyarakat merupakan alat komunikasi berdakwah, semakin besar dukungan dakwah semakin besar harapan keberhasilan dakwahnya. Dakwah ini dapat berhasil apabila didasari kepercayaan yang diakui oleh masyarakat. Hal ini sesuai dengan pendapat Melton yang dikutip oleh Marisson, bahwa tingkah laku manusia berdasarkan kepercayaan sikap dan nilai. ${ }^{36}$

Dapat dikatakan bahwa, perlindungan hukum bagi orang yang beragama perlu dipenuhi hak mereka. Karena perlindungan ini sudah dijelaskan dalam Al-Quran, al-hadits, dan pendapat para ahli. Ini dilakukan dengan tujuan agar pemeluk suatu agama mendapat perlindungan hukum dan dapat mengembangkan (dakwah) pada masyarakat sekitarnya bahkan sampai wilayah yang lebih luas.

\section{b. Perlindungan dakwah yang beragama di antaranya kebebasan, rasionalitas, dan universal.}

Pertama, Perlindungan hukum dalam kebebasan, artinya pengayoman terhadap ajakan seseorang atau kelompok dalam menjalankan tugas sebagai seorang $d a^{\prime} i$. Ini dilakukan untuk mengajak orang lain agar mengikuti ajaran atau agamanya. Dakwah ini sudah diisyaratkan oleh Al-Quran,

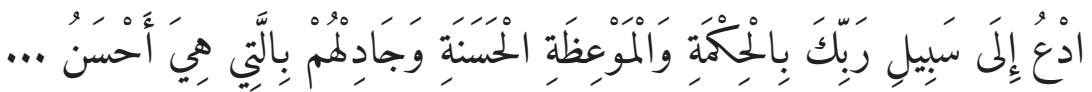

Artinya: "Ajaklah (manusia) kepada jalan Tuhan-mu dengan hikmah dan pelajaran yang baik dan bantablah mereka dengan cara yang baik."37

Kebebasan dakwah ini juga dicontohkan oleh Rasul, artinya: "Ajaklah kepada agama Allah dan kamu patuh dapat terkabulnya."38

Kebebasan dakwah ini juga dilaksanakan Rasul ketika beliau berhadapan dengan kafir Qurais berada di Kota Mekah. Hal ini telah diterangkan oleh A. Sya’labi, bahwa Rasul menyeru segenap lapisan manusia kepada ajaran Islam dengan terang-terangan, baik golongan bangsawan maupun lapisan hamba sahaya, begitu juga kaum kerabat sendiri maupun orang lain. ${ }^{39}$

Dakwah merupakan komunikasi dengan masyarakat baik seagama maupun masyarakat yang berbeda agamanya. Komunikasi dakwah ini akan saling

\footnotetext{
${ }^{36}$ Marisson, Op.Cit, hal. 104.

${ }^{37}$ QS. An-Nahl: 125.

${ }^{38}$ Abu Bakar Al-Suyuthi, Op.Cit, hal. 15.

${ }^{39}$ A. Sya'labi, Op.Cit, hal. 86.
} 
memberikan sikap kesopanan dan memberikan perlindungan supaya mereka tetap terjaga dan terlindungi. Menurut Brown dan Levinson, setiap kebudayaan memiliki derajat yang berbeda dalam hal kebutuhan terhadap kesopanan dan cara yang berbeda untuk menjadi sopan, tetapi semua orang memiliki kebutuhan untuk dihargai dan dilindungi. ${ }^{40}$

Keterangan ini menunjukkan bahwa interaksi sosial dengan tujuan untuk mendapatkan penghargaan dan perlindungan diri masing-masing, termasuk hubungan antarumat beragama.

Kedua, Perlindungan hukum berpikir rasional, artinya dalam melakukan dakwah melalui berpikir, berdebat dan berargumen dan untuk memberi penilaian suatu kasus yang muncul. Berdebat dengan argumen ini telah ditetapkan oleh Al-Quran, artinya: "dan berdebatlah dengan cara yang baik. ${ }^{41}$ Debat yang baik dapat mencapai pemikiran yang luas sehingga muncul gagasan yang baik, dapat melindungi pada dirinya dan pihak lain, termasuk pemeluk agama yang berbeda.

Perlindungan rasionalitas ini juga dilakukan oleh Rasul, bahwa beliau telah mengulang-ulang suatu pernyataan sampai tiga kali dengan tujuan agar memberikan perlindungan akal mereka dalam memahami hasil pemikiran. Beliau bersabda, artinya: "Rasul adalah mengulang perkataan sampai tiga kali agar diterima akal, pada pengulangan itu." ${ }^{2}$

Perlindungan rasionalitas ini dapat dilakukan dengan cara mengadakan pendekatan rasional mengandalkan pada aturan lokal yaitu memberikan giliran secara bergantian antar pembicara agar teratur dan diterima akal. Hal ini telah dikemukakan dalam Teori Komunikasi, bahwa bagi pendukung pendidikan rasional, berdasarkan urutan percakapan yang telah dijelaskan sebelumnya disebut dengan menggunakan aturan lokal (local rulers) yang berarti giliran bicara diatur secara bergantian. ${ }^{43}$

Ringkasan keterangan ini, bahwa perlindungan rasionalitas dengan cara mengatur pembicara di antara mereka dengan bergiliran satu sama lain agar teratur dan saling terlindungi nilai pembicaraannya, termasuk di dalamnya masalah hak berbicara dalam beragama.

Ketiga, Perlindungan hukum universal, artinya perlindungan terhadap semua insan, karena mereka adalah objek dakwah, perlu disentuh melalui ni-

\footnotetext{
40 Marisson, Op.Cit, hal. 171.

${ }^{41}$ QS. An-Nahl: 125.

${ }^{42}$ Abu Bakar Al-Suyuthi, Op.Cit, hal. 119.

${ }^{43}$ Marisson, Op.Cit, hal. 247.
} 
lai-nilai dakwah itu. Perlindungan universal ini termasuk semua orang tanpa membedakan ras atau strata sosial termasuk sasaran pemeluk agama yang berbeda atau orang yang belum beragama. Perlindungan ini bertujuan agar mereka memiliki pengetahuan tentang agama dan dapat berbuat kebaikan melalui ajaran agama ini. Hal ini dikemukakan oleh Al-Faruqi, bahwa Islamlah mengenal pembalasan seperti itu. Islam menantang semua orang mempunyai kewajiban mendengarkan bukti dan memberi penilaian. ${ }^{44}$

Perlindungan universal ini telah diatur dalam Al-Quran dengan cara Allah memberikan kasih sayang terhadap seluruh makhluk di seluruh alam ini. Allah berfirman,

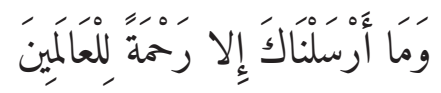

Artinya: "Dan tiadalah Kami mengutuskamu, melainkan untuk (menjadi) rahmat bagi semesta alam."

Perlindungan ini mengandung nilai pengayoman terhadap siapapun, tanpa memandang ras, suku dan agama, mereka berhak mendapat pengayoman dari Tuhan Yang Maha Pelindung.

Keempat, Perlindungan hukum dalam maisyah (Sumber Ekonomi). Perlindungan maisyah yaitu suatu pengayoman terhadap sumber ekonomi atau mata pencaharian bagi seseorang walaupun berbeda agamanya. Ini dilakukan karena sumber ekonomi adalah sarana untuk menghidupi mereka agar mereka dapat hidup sejahtera dan dapat menjalankan agama mereka dengan baik. Perlindungan maisyah ini telah ditetapkan dalam Al-Quran,

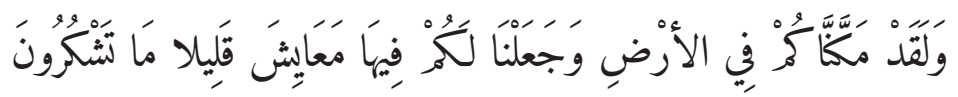

Artinya: "Sesungguhnya Kami telah menempatkan kamu sekalian di muka bumi dan Kami adakan bagimu di muka bumi (sumber) penghidupan. Amat sedikitlah kamu bersyukur."

Al-Quran telah memberikan perlindungan maisyah (sumber ekonomi) kepada siapapun, baik orang Islam maupun orang yang beda agama, sebagai pemenuhan kebutuhan konsumsi agar mereka dapat hidup di bumi ini.

\footnotetext{
${ }^{44}$ Ismail R. Al-Faruqi, Lois Lamya Al-Faruqi, Atlas Budaya Islam, Bandung: Mizan, 2003, hal. 222.

${ }^{45}$ QS. Al-Anbiya': 107.

${ }^{46}$ QS. Al-A'raf: 10.
} 
Perlindungan sumber ekonomi (maisyah) ini juga disabdakan oleh Rasul saw, artinyaL "Ya Allah aku mohon perlindungan dari fakir." Pada hadits yang lain diterangkan, artinya: "Ya Allah aku mohon perlindungan dari kelaparan." ${ }^{47}$

Perlindungan maisyah (sumber ekonomi) dapat dilakukan dengan cara menjalin hubungan sosial (interaksi sosial) dengan orang lain walaupun terdapat perbedaan suku, ras, bangsa atau agama. Karena interaksi sosial ini dapat menjadikan sarana hubungan ekonomi yang saling menguntungkan. Dalam Teori Sosiologi diterangkan oleh Homans, ia melihat perilaku sosial dari hasil pertukaran, pekerjaan tidak hanya menyediakan ganjaran ekstrinsik berupa upah, tetapi juga menyediakan upah interinsik berupa persahabatan. ${ }^{48}$ Dengan menjalankan perukaran perilaku yang mendapatkan ganjaran ekonomi dapat mendukung sumber kehidupan sesama. Ini dapat mengakibatkan perlindungan ekonomi sesama walaupun beda agama atau ras.

Keterangan ini dapat diringkas bahwa perlindungan pemeluk sesama agama dapat dilakukan melalui interaksi sosial yang mengandung ganjaran berupa nilai ekonomi yang telah mendapat pelindungan hukum dari Al-Quran dan hadits Nabi.

\section{KESIMPULAN}

Hak asasi manusia beragama, merupakan hak seseorang dalam memeluk suatu agama yang diyakini kebenarannya. Pada dasarnya hak asasi manusia beragama adalah kebebasan seseorang dalam memeluk suatu agama yang dipercayai kebenarannya. Hak Asasi Manusia dalam Perspektif Tafsr Izwaji meliputi:

1. Hak iman, mencakup ikrar dengan lisan, pembenaran dengan hati dan pembenaran melalui amal perbuatan anggota badan.

2. Hak pengamalan, mencakup prinsip kepatuhan, prinsip pemenuhan, hak prinsip dan keadilan.

3. Hak perlindungan, mencakup perlindungan fisik dan hukum, mencakup ekspresi pemikiran, dakwah, di dalamnya meliputi kebebasan, rasional dan universal dakwah, serta perlindungan maisyah (sumber ekonomi) di antara sesama pemeluk agama.

\footnotetext{
${ }^{47}$ Abu Bakar Al-Suyuthi, Op.Cit, hal. 61.

${ }^{48}$ Margaret M. Polma, Op.Cit, hal. 59.
} 


\section{DAFTAR PUSTAKA}

Ahmad Nur Fuad, dkk. "Islam and Human Rights in Indonesia: An Account of Muslim Intellectual." Al-Jamiah Journal Of Islamic Studies (UIN Sunan Kalijaga Yogyakarta) 45, no. 2 (2007/1428).

Aisyah. "Hak Asasi Manusia Dalam AL Qur'an." Tafsere (UIN Alaudin Makasar) 2, no. 1 (2014).

Al- Bukhari, Abu Abdullah bin Muhammad bin Ismail. Shahih Bukhari, Juz III Cet. 3. Beirut: Dar Ibnu Katsir, 1981.

Al- Ja'afi, Abu Abdullah Muhammad bin Ismail al-Bukhari. Shahih Bukhari. Juz III Cet. ke 3. Bairut: Dar Ibnu Katsir., n.d.

Al- Kalabadzi, Abi Bakar Muhammad bin Ishak. Al-Al-TáarrufLi madzahibi Abli Al-Tasawwuf. Beirut: Darul Kutub Al-Ilmiyah, 1993.

Al Qur'an dan Terjemahannya. Wakaf dan Pelayanan Tanah Suci Raja Fahd bin Abdul Aziz Al Saud, n.d.

Al-Suyuthi, Al-Imam Jalaluddin Abdu Al-Rahman bin Abi Bakar. Al-Jami'u Al-Shaghir. Bandung-Indonesia: Syirkah Al-Ma’arif, n.d.

Hafniati. "Hak Asasi Manusia Dalam Islam." Al Adyan (Prodi Studi AgamaAgama Fakultas Ushuludin IAIN Raden Intan) 3, no. 2 (JuliDesember 2018).

Harun Nasution dan Bahtiar Effendy. Hak-Hak Asasi Manusia Dalam Islam.

Cet. ke 2. Jakarta: Yayasan Obor Indonesia, 1995.

Ismail R. Al- Faruqi, Lois Lamya. Atlas Budaya Islam. Bandung: Mizan, 2003. Katsir, Ibnu. Tafsir Al-Quranul Adzim. Cet. II Jilid 4. n.d.

Kurniawan Kunto Yuliarso, Nunung Prajarto. "Hak Asasi Manusia (HAM) Di Indonesia: Menuju Democratic Governance." JSP: Jurnal Ilmu Sosial Dan Ilmu Politik 8, no. 3 (Maret 2005).

Marisson. Teori Komunikasi Individu Hingga Massa. Jakarta: Kencana Prenada Media Grup, 2013.

Nasution, Harun. Teologi Islam, Aliran-Aliran Sejarah, Analisa Perbandingan. Cet. V. Jakarta: UI Press, 1986.

Polma, Margaret M. Sosiologi Kontemporer. Jakarta: PT. Raja Grafindo Persada, 2000.

Pulungan, J. Suyuthi. Universalisme Islam. Jakarta: PT. Moyo Segoro Agung, 
2002.

Sidney Hook, dkk. Hak Azazi Manusia Dalam Islam. Jakarta: Pustaka Firdaus, 1995.

Syalabi, A. Sejarah dan Kebudayaan Islam. Jakarta: Percetakan Mutiara Sumber Wijaya, 2000.

Yatim, Badri. Sejarah Peradaban Islam, Dirasah Islamiyah. Jakarta: Raja Grafindo Indonesia, 2000. 